\section{Chilling, Ethephon, and Photoperiod Affect Cormel Production of Brodiaea}

\author{
S.S. Han \\ Department of Plant and Soil Sciences, French Hall, University of \\ Massachusetts, Amherst, MA 01003
}

Additional index words. Triteleia laxa, temperature, seed germination

\begin{abstract}
Stratification by chilling is the primary factor controlling germination of brodiaea (Triteleia laxa Benth.) seeds. A minimum of 8 weeks of low temperature (3C) was required for maximum germination. Soaking seeds in a solution of $1000 \mathrm{mg}$ ethepho/liter for $20 \mathrm{~h}$ reduced the number of weeks at low temperature required for germination. Cormel size was affected by the photoperiod during seedling growth. Long days induced early leaf senescence, and cormels harvested from seedlings grown under long days weighed only half as much as those grown under short days. Chemical name used: 2chloroethyl phosphoric acid (ethephon).
\end{abstract}

Brodiaeas are cormous plants that produce inflorescences used commercially as cut flowers. The corms are replaced annually by daughter corms. Depending on the size of the mother corm, a variable number of small cormels form at the base of each axillary shoot (Han et al., 1991). Asexual propagation by this method does not produce enough propagules for successful commercial production of this crop.

Brodiaea flowers are self-incompatible (Niehaus, 1971) outproduce an ample number of seeds when cross-pollinated. For commercial corm production in The Netherlands, seeds are sown in mid-September, and the corms are harvested after the second growing season. The corms are graded into two sizes based on their circumference and are replanted in November. After the third growing season, the corms are sorted into commercial-sized or noncommercial-sized (small) corms. The small corms are replanted and are harvested for sale the following year (Langeslag, 1989). This sexual propagation schedule requires 3 or 4 growing seasons to produce commercial-sized corms.

Environmental factors, such as temperature and light, affect seed germination of many plant species. Seeds often require a period of high or low temperature to break seed dormancy and permit germination. Photoperiod controls growth and development of many plant species, and in brodiaeas, long days reduce the percentage of flowering (Fortanier, 1969; Han et al., 1991) and result in early development of leaf yellowing (Fortanier, 1969). The effects of photoperiod on the production of brodiaea cormels is not known.

Ethylene $\left(\mathrm{C}_{2} \mathrm{H}_{4}\right)$ promotes seed germination in many plant species (Hartmann et al., 1990). Application of exogenous ethylene has been used to study the role of this plant hormone on seed germination. Ethylene can be

\footnotetext{
Received for publication 4 Feb. 1993. Accepted for publication 8 June 1993. The cost of publishing this paper was defrayed in part by the payment of page charges. Under postal regulations, this paper therefore must be hereby marked advertisement solely to indicate this fact.
}

applied either by exposing seeds to ethylene gas or by soaking seeds in solutions of ethephon (Goudey et al., 1987). Soaking seeds is more convenient, and studies on Chenopodium album L. seeds demonstrated that both methods resulted in the same physiological responses (Goudey et al., 1987).

Information on environmental factors required for successful seed germination and subsequent seedling growth is important for mass production of brodiaeas. No reports were found on the environmental conditions required for seed germination and cormel production of brodiaeas. The objectives of this study were to investigate the role of temperature and ethephon on seed germination and the effects of photoperiod on cormel production of brodiaeas.

Temperature (Expt. 1). Brodiaea seeds collected from the field at the Univ. of California, Davis, were stored at $20 \pm 3 \mathrm{C}$ until the experiments commenced. In November, seeds either were sown in $15.5 \times 11 \times 6-\mathrm{cm}$ plastic trays or were held dry in containers at $3 \mathrm{C}$ in dark growth chambers for 0 to 10 weeks. Seeds sown in trays were covered with $\approx 3 \mathrm{~mm}$ of propagation medium (Redi-earth peat-lite mix; Grace Horticultural, Cambridge, Mass.) and were kept moist during the low-temperature treatment. At 2-week intervals, flats were transferred to a $26.7 / 21.7 \mathrm{C}$ (maximum/minimum) glasshouse with intermittent periods of mist. Seed germination was evaluated under natural daylight. Seed was considered germinated when the cotyledon became visible. Percent seed germinated was determined at 1-week intervals. The design was a randomized complete block with 100 seeds each and three blocks per treatment. Regression analysis was used to test the relationships between the length of low-temperature treatment and total germination percentages, number of days to $50 \%$ final germination $\left(\mathrm{T}_{50}\right)$ and the number of days between $10 \%$ and $90 \%$ final germination $\left(\mathrm{T}_{90}-\mathrm{T}_{10}\right)$.

Low temperature and ethephon (Expt. 2). Seeds were soaked in aerated ethephon solutions of 0,100 , or $1000 \mathrm{mg} \cdot l i t e r^{-1}$ for $20 \mathrm{~h}$. Following the treatment, seeds were sown in trays and placed at $3 \mathrm{C}$ in dark chambers for 0 , $2,4,6,8$, or 10 weeks. The design consisted of randomized blocks of 50 seeds each and three blocks per treatment. Germination was evaluated as described in Expt. 1. Total germination percentages and $\mathrm{T}_{50}$ were calculated and statistically analyzed. The total percentage data was transformed (arcsin $\left.V_{p}\right)$ and single degree-offreedom contrasts were used to compare treatments (Gomez and Gomez, 1984).

Photoperiod (Expt. 3). Seeds sown in trays as described in Expt. 1 were placed at $3 \mathrm{C}$ in dark chambers for 8 weeks to fulfill the lowtemperature requirement for maximum seed germination. Flats were then moved to a $26.7 /$ 21.7C (maximum/minimum) glasshouse with intermittent periods of mist. After $60 \%$ of the seeds had germinated, half of the trays were moved to short-day conditions ( $8 \mathrm{~h}$ natural light, black cloth between 1600 and $0800 \mathrm{HR}$ ) and the others to long-day conditions ( $8 \mathrm{~h}$ natural light plus night interruption with 3.6 $\mu \mathrm{mol} \cdot \mathrm{s}^{-1} \cdot \mathrm{m}^{-2}$ incandescent lamp between 2200 and $0200 \mathrm{HR}$ ). The medium in flats was fertilized weekly with $20 \mathrm{~N}-10 \mathrm{P}-20 \mathrm{~K}$ at $200 \mathrm{mg} \mathrm{N} /$ liter and remained under the benches until all leaves had senesced, at which time cormels were harvested and weighed. The design was a complete block with 50 seeds each and five blocks per treatment. Seed germination was $8190 \pm 2 \%$; thus, fresh weights of 200 cormels were recorded for each treatment.

Brodiaea seeds required moist prechilling for germination. Chilling dry seeds for up to 12 weeks resulted in no germination during 90 days in the greenhouse. Imbibed seeds required more than 2 weeks of chilling for germination. Total germination percentages increased as the chilling period increased, and maximum germination was achieved after seeds were chilled for 8 weeks or longer (Table 1). In addition, increasing length of chilling significantly reduced the $\mathrm{T}_{50}$ and $\mathrm{T}_{90}-\mathrm{T}_{10}$, indicating that low temperature promotes earlier and more uniform sprouting of the seeds.

Ethylene increased total germination percentages only for seeds that had been partially chilled -4 weeks in this study (Table 2). Total germination percentages of seeds treated with 100 or $1000 \mathrm{mg}$ ethephon/liter and prechilled for 4 weeks were significantly higher $(P \leq$ $0.001)$ than that of nontreated seeds. Seeds treated with $1000 \mathrm{mg}$ ethephon/liter or with water and then chilled for 4 weeks had $60 \%$ and $35 \%$ germination, respectively. There were no differences between seeds treated with 100 or $1000 \mathrm{mg}$ ethephon/liter. Neither non stratified (chilled for 0 or 2 weeks) nor fully stratified seeds (6 or more weeks of low temperature) responded to the ethephon treatment.

The physiological role of ethephonin stimulating the germination of brodiaea seeds appears to differ from its role in redroot pigweed (Amaranthus retroflexus L.) seeds. In the latter, ethylene promotes splitting of the seedcoats and later the emergence of the radicle through the endosperm (Schonbeck and Egley, 1980, 1988). Without the ethephon treatment, 30\% to $50 \%$ of redroot pigweed seeds did not complete the germination process and paused after the seedcoat split. Exogenous ethylene in- 
Table 1. Effect of $3 \mathrm{C}$ low-temperature exposure on germination of imbibed brodiaea seeds.

\begin{tabular}{lccc}
\hline $\begin{array}{l}\text { Low-temperature } \\
\text { exposure } \\
\text { (weeks) }\end{array}$ & $\begin{array}{c}\mathrm{T}_{50}{ }^{2} \\
\text { (days) }\end{array}$ & $\begin{array}{c}\mathrm{T}_{90}-\mathrm{T}_{10}{ }^{\mathrm{y}} \\
\text { (days) }\end{array}$ & $\begin{array}{c}\text { Total } \\
\text { germination } \\
(\%)\end{array}$ \\
\hline 0 & --- & -- & 0 \\
2 & -- & $-\cdots-$ & 0 \\
4 & $20.9 \pm 1.0$ & $15.6 \pm 1.2$ & $34.3 \pm 1.4$ \\
6 & $12.1 \pm 0.2$ & $7.2 \pm 0.9$ & $76.1 \pm 4.2$ \\
8 & $9.8 \pm 0.3$ & $7.0 \pm 0.2$ & $87.0 \pm 2.1$ \\
10 & $9.2 \pm 0.0$ & $5.0 \pm 0.1$ & $89.1 \pm 0.7$ \\
Linear regression & $* * *$ & $* *$ & $* *$ \\
Quadratic regression & $* *$ & $*$ & $*$ \\
\hline
\end{tabular}

${ }^{2}$ Number of days to $50 \%$ of final germination.

Number of days from $10 \%$ to $90 \%$ germination.

${ }^{*, * *, * * *}$ Significant at $P \leq 0.05,0.01$, or 0.001 , respectively. duced all incompletely germinated seeds to germinate (Schonbeck and Egley, 1988). Unlike redroot pigweed seeds, where complete germination of the ethephon-treated seeds occurred in 3 to 4 days, brodiaea seeds germinated in 6 weeks (4 weeks stratification plus 2 weeks for the seeds to germinate) after the ethephon treatment (Table 2). Ethephon does not remain active for prolonged periods (Warner and Leopold, 1969). The timing of germination of the brodiaea seeds thus suggests that ethephon may not influence the splitting of the seedcoat or emergence of the radicle. (Table 2). Improved germination was reported on tickseed (Coreopsis lanceolata L.) (Carpenter and Ostmark, 1992) and lettuce (Lactuca sativa L.) (Zeng and Khan, 1984) seeds treated with ethephon and gibberellins. The germination-promoting effects of both regulators are similar in these two crops, suggesting that ethephon promotes germination by enhancing the synthesis of $\mathrm{GA}_{3}$ (Carpenter and Ostmark, 1992). In contrast, soaking brodiaea seeds in 100-mg GA/liter solutions, as was done in the ethephon study, neither affected the total germination percentage nor the germination rate (data not shown). The differences among brodiaea, tickseed, and lettuce may be due to the lower concentration of $\mathrm{GA}_{3}$ used in the brodiaea study or maybe due to differences in the mechanism by which ethephon promotes seed germination of different plant species.

After germination, the brodiaea cotyledons continue to grow and elongate during the entire growing season. Photosynthate is translocated to the base of the cotyledon, thus leading to the formation and enlargement of the cormels (Han, 1988). Cormels harvested after the first growing season from seedlings grown under long days weighed about half (40 $\pm 1.4 \mathrm{mg}$ ) of those grown under short days (70 $\pm 2.5 \mathrm{mg}$ ). The cormels harvested from seedlings grown under long-day conditions most likely were smaller because of premature yellowing of brodiaea leaves, as observed in this study and reported by Fortanier (1969). Replanting brodiaea cormels resulted in larger
Table 2. Germination of brodiaea seeds treated with various concentrations of ethephon before lowtemperature exposure. Data are means $\pm \mathrm{SE}$.

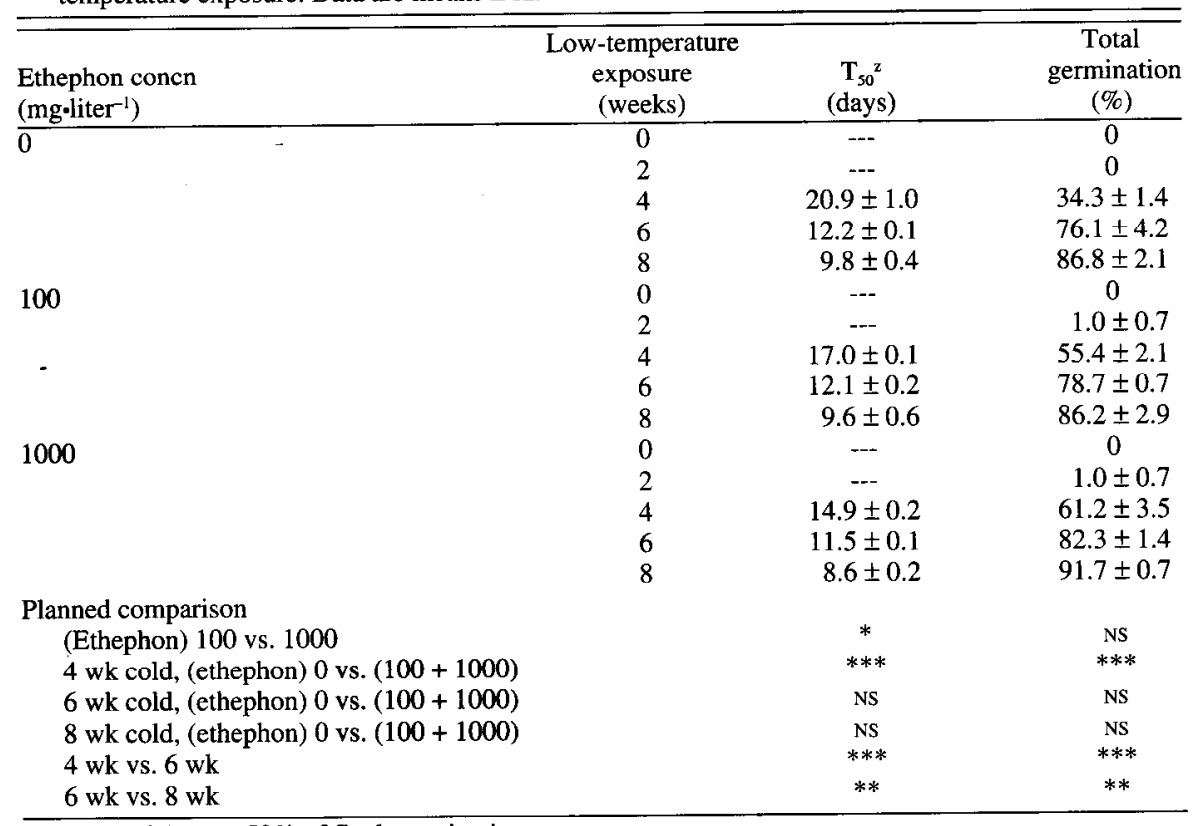

${ }^{2}$ Number of days to $50 \%$ of final germination.

Ns. "***,*** Nonsignificant or significant at $P \leq 0.05,0.01$ or 0.001 , respectively. replacement corms after one growing season (Han et al., 1991). Regression analysis of the data reported in Han et al. (1991) showed a significant relationship between the weights of the daughter corm (D) and mother corm $(\mathrm{M}), \mathrm{D}=0.59+6.13 \mathrm{M}-0.53 \mathrm{M}^{2}, r=0.998$. Based on this equation, corms harvested from plants grown under long and short days should theoretically weigh $\approx 2.4$ and $\approx 4.45 \mathrm{~g}$, respectively, after the third growing season. We have reported previously that the minimum corm weight for brodiaea to flower is $1.1 \mathrm{~g}$, provided that the corms are stored properly (Han et al., 1991). Extended storage (i.e., 6 months or more) reduces the flowering potential (Han, unpublished data). To compensate for the loss in flowering potential with increasing storage time, corms 4 to $5 \mathrm{~cm}$ and $>5 \mathrm{~cm}$ in circumference (comparable to $\approx 2.5 \mathrm{~g}$ and heavier) are sold commercially for forcing. producing these large corms requires three or four growing seasons in The Netherlands (Langeslag, 1989), and results of this study correspond to the commercial practice.

In summary, to produce brodiaea corms sexually, imbibed seeds should be exposed to a minimum of 8 weeks of low temperature for maximum and uniform germination. Soaking seeds in $1000 \mathrm{mg}$ ethephon/liter for $20 \mathrm{~h} \mathrm{be-}$ fore the chilling treatment increased germination of partially stratified seeds. This practice can be helpful in regions where low-temperature duration may be inadequate. Long days promoted early leaf senescence and resulted in production of smaller cormels.

\section{Literature Cited}

Carpenter, W.J. and E.R. Ostmark. 1992. Growth regulators and storage temperature govern germination of coreopsis seed. HortScience 27:1190-1193.

Fortanier, E.J. 1969. The influence of temperature, light energy and photoperiod on flowering of Brodiaea laxa Wats. Netherlands J. Agr. Sci. 17:176-182.

Gomez, K.A. and A.A. Gomez. 1984. Statistical procedures for agricultural research. 2nd ed. Wiley, New York.

Goudey, J.S., H.S. Saini, and M.S. Spencer. 1987. Uptake and fate of ethephon ([2chloroethyl]phosphonic acid) in dormant weed seeds. Plant Physiol. 85:155-157.

Han, S.S. 1988. Control of growth, flowering, and flower senescence in Triteleia laxa. PhD Diss., Univ. of California, Davis.

Han, S.S., A.H. Halevy, R.M. Sachs, and M.S. Reid. 1991. Flowering and corm yield of brodiaea in response to temperature, photoperiod, corm size and planting depth. J. Amer. Soc. Hort. Sci. 116:19-22.

Hartmann, H.T., D.E. Kester, and F.T. Davies, Jr. 1990. Plant propagation principles and practices. 5th ed. Prentice Hall, Englewood Cliffs, N.J.

Langeslag, J.J.J. 1989. Teelt en Gebruiksmogelijkheden van Bijgoedgewassen. Tweede Uitgave. Ministerie van Landbouw, Natuurbeheer en Visserij en Consulentschap Algemene Dienst Bloembollenteelt, Lisse, The Netherlands.

Niehaus, T.F. 1971. A biosystematic study of the genus Brodiaea (Amaryllidaceae). Univ. of California Publ. Bot. 60 
Schonbeck, M.W. and G.H. Egley. 1980. Effects of temperature, water potential, and light on germination responses of redroot pigweed seeds to ethylene. Plant Physiol. 65:1149-1154.

Schonbeck, M.W. and G.H. Egley. 1988. Effects of ethylene and some other environmental factors on different stages of germination in redroot pigweed (Amaranthus retroflexus L.) seeds. Plant Cell Environ. 11:189-197.

Warner, H.L. and A.C. Leopold. 1969. Ethylene evolution from 2-chloroethylphosphonic acid. Plant Physiol. 44:156-158.
Zeng, G.W. and A.A. Khan. 1984. Alleviation of high temperature stress by preplant permeation of phthalimide and other growth regulators into lettuce seed via acetone. J. Amer. Soc. Hort. Sci. 109:782-785. 